\title{
Lack of direct evidence for a functional role of voltage-operated calcium channels in juxtaglomerular cells
}

\author{
Armin Kurtz ${ }^{1}$, Ole Skott ${ }^{2}$, Soheil Chegini ${ }^{1}$, and Reinhold Penner ${ }^{3}$ \\ ${ }^{1}$ Physiologisches Institut der Universität, Winterthurerstrasse 190, CH-8057 Zürich, Switzerland \\ ${ }^{2}$ University Institute of Experimental Medicine, Copenhagen, Denmark \\ ${ }^{3}$ Abteilung Membranbiophysik, Max-Planck-Institut für Biophysikalische Chemie, Göttingen, Federal Republic of Germany
}

Received November 8, 1989 / Received after revision January 8/ Accepted January 15, 1990

\begin{abstract}
In this study we have examined the role of voltagegated calcium channels in the regulation of calcium in juxtaglomerular cells. Using a combination of patch-clamp and single-cell calcium measurement we obtained evidence neither for voltage-operated calcium currents nor for changes of the intracellular calcium concentration upon acute depolarizations of the cell membrane. Increases of the extracellular concentration of potassium to $80 \mathrm{mmol} / \mathrm{l}$ depolarized the juxtaglomerular cells close to the potassium equilibrium potential, but did not alter the intracellular calcium concentration neither in patch-clamped nor in intact Furaester-loaded cells. Moreover, basal renin secretion from a preparation enriched in mouse juxtaglomerular cells and from rat glomeruli with attached juxtaglomerular cells was not inhibited when extracellular potassium was isoosmotically increased to $56 \mathrm{mmol} / \mathrm{l}$. In mouse kidney slices, however, depolarizing potassium concentrations caused a delayed inhibition at $56 \mathrm{mmol} / \mathrm{l}$ and a delayed stimulation of renin secretion at $110 \mathrm{mmol} / \mathrm{l}$. Taken together, our study does not provide direct evidence for a role of voltage-activated calcium channels in the regulation of calcium and renin secretion in renal juxtaglomerular cells.
\end{abstract}

Key words: Renin secretion - Patch clamp - Calcium measurement

\section{Introduction}

The regulation of exocytosis of renin-containing granules from renal juxtaglomerular (JG) cells displays an exceptional feature. While the intracellular concentration of calcium either initiates, facilitates or maintains secretion in typical exo- and endocrine cells (Penner and Neher 1988), it appears to be inhibitory for renin secretion (Churchill 1988). On the basis of indirect evidence it is thought that voltage-gated calcium channels play an important role in

Offprint requests to: A. Kurtz the regulation of $[\mathrm{Ca}]_{i}$ in JG cells and in consequence in the regulation of renin secretion (Churchill 1988). It has been found that calcium antagonists, such as verapamil, have a stimulatory effect on renin secretion in vivo (Abe et al. 1983). A rise of extracellular potassium that depolarizes JG cells (Fishman 1976) inhibits renin secretion in a calciumdependent fashion both in isolated kidneys (Fray 1978) and in renal cortical slices (Churchill 1980; Matsumura et al. 1984; Park et al. 1981; Churchill 1987; Frax et al. 1987).This effect of potassium is attenuated by calcium channel blockers (Churchill 1980, 1987, 1988; Park et al. 1981). Conversely, calcium channel agonists, such as Bay K 8644, were found to inhibit renin secretion from kidney slices (Fray et al. 1987; Matsumura et al. 1985).

A direct demonstration of voltage-gated calcium channels and an investigation of their possible role in the regulation of intracellular calcium in renal juxtaglomerular cells is still lacking. Recently we have presented a method to gain insight into electrical events and the regulation of intracellular calcium in single JG cells (Kurtz and Penner 1989). Using this technique we have studied the role of voltagegated calcium channels in the regulation of calcium in JG cells. Much to our surprise, however, we did not obtain any evidence for a functional role of voltage-gated $\mathrm{Ca}^{2+}$, channels in mouse renal JG cells.

\section{Materials and methods}

Tissue preparation for patch-clamp study

For one preparation both kidneys from a female NMRI (Naval Medical Research Institute) mouse, 6-8 weeks old, were used. The animal was killed by cervical dislocation, and the kidneys were removed, decapsulated, and minced with a scalpel blade.The material was incubated with gentle shaking at $37^{\circ} \mathrm{C}$ in $30 \mathrm{ml}$ standard saline solution (in mmol/1: $140 \mathrm{NaCl}, 2.8 \mathrm{KCl}, 2 \mathrm{CaCl}_{2}, 1 \mathrm{MgCl}_{2}, 11$ glucose, $10 \mathrm{HEPES} /$ $\mathrm{NaOH}, \mathrm{pH} 7.2$ ) supplemented with $30 \mathrm{mg}$ collagenase. After $25 \mathrm{~min}$ the suspension was sifted over $150-\mu \mathrm{m}$ and $50-\mu \mathrm{m}$ screens. The material retained by the $50-\mu \mathrm{m}$ screen was washed in $10 \mathrm{ml}$ saline and settled in a bench-top centrifuge. The pellet was resuspended in $1 \mathrm{ml}$ saline and subsequently plated in the recording chamber. The tissues that attached to the glass surface consisted mainly of glomeruli, which had 
afferent arterioles of different lengths. From these structures celis at a distance between $5 \mu \mathrm{m}$ and $100 \mu \mathrm{m}$ were selected for patch-clamp and calcium measurement experiments (Kurtz and Penner 1989).

\section{Patch-clamp experiments}

Experiments were performed at room temperature in standard saline buffer. Patch-clamp measurements were done with Sylgard-coated pipettes $(5-10 \mathrm{M} \Omega)$ in whole-cell configuration. The standard solution for filling pipettes (intracellular solution) contained (in mmol/1) 135 potassium glutamate, $10 \mathrm{NaCl}, 1 \mathrm{MgCl}_{2}, 10 \mathrm{HEPES} / \mathrm{NaOH}, 0.5 \mathrm{Mg}$ / ATP, 0.3 GTP, 0.1 Fura-2 pentapotassium salt ( $\mathrm{pH} 7.2$ ).

Fluorescence measurements on single cells were performed as described (Neher 1988). Patched cells were loaded with Fura-2 by diffusion from the recording pipette and intact cells were loaded with Fura2 acetoxymethyl ester according to standard protocols. Fluorescence of Fura- 2 was excited alternately by light at $360 \mathrm{~nm}$ and $390 \mathrm{~nm}$ by means of a rotating filter wheel fitted to a slot in the excitation pathway of the microscope. [Ca) i $_{\mathrm{i}}$ was calculated from the fluorescence ratio (Grynkiewicz et al. 1985). Application of angiotensin II, ionomycin and buffer containing high $\mathrm{K}$ was done by pressure ejection from a second pipette (Kurtz and Penner 1989).

For this study a total of 150 cells prepared from 54 mice was examined.

\section{Experiments on renin secretion}

The effect of extracellular potassium on renin secretion from mouse and rat renal tissues was examined.

\section{Mouse tissue}

Renin release from tissue suspension. Material retained by the $50-\mu \mathrm{m}$ screen, as described above, was washed, loaded on two Sephadex G-50 columns ( $100 \mu \mathrm{l}$ bed volume) and superfused with standard buffer at a rate of $100 \mu \mathrm{l} / \mathrm{min}$. Effluent was sampled at 5 -min intervals, frozen and stored at $-20^{\circ} \mathrm{C}$ until assay of renin activity. Renin activity was determined by the generation of angiotensin I from the plasma of bilaterally nephrectomized rats (Kurtz et al. 1986). Angiotensin I was determined by radioimmunoassay. Superfusion was performed for 120 min. Samples were taken between the 50 th and 115 th min of superfusion. Changes of buffers were made between the 75 th and 95 th min, as a rule.

Renin release from kidney slices. Both kidneys of a mouse were immediately removed after cervical dislocation and cooled for $5 \mathrm{~min}$ at $4^{\circ} \mathrm{C}$ in standard buffer (in mmol/l: $118.5 \mathrm{NaCl}, 4.7 \mathrm{KCl}, 2.0 \mathrm{CaCl}_{2}$, $1.2 \mathrm{KH}_{2} \mathrm{PO}_{4}, 1.2 \mathrm{MgSO}_{4}, 25 \mathrm{NaHCO}_{3}, 10$ glucose) equilibrated with $95 \% \mathrm{O}_{2} / 5 \% \mathrm{CO}_{2}$. The kidneys were decapsulated and cut into slices of $100 \mu \mathrm{m}$ thickness with a McIlwain tissue chopper (Mickle Lab. Engineering Co., Guildford, U.K.). The slices were washed twice in $30 \mathrm{ml}$ cooled and gassed standard buffer for $5 \mathrm{~min}$. The slices obtained from 1 mouse were subsequently transferred to six petri dishes $\left(7 \mathrm{~cm}^{2}\right)$ containing $2 \mathrm{ml}$ gassed and prewarmed $\left(37^{\circ} \mathrm{C}\right)$ standard buffer. The dishes were placed on a heater maintaining a temperature of $37^{\circ} \mathrm{C}$ and they were gassed continuously with $95 \% \quad \mathrm{O}_{2} / 5 \% \mathrm{CO}_{2}$. Buffer was exchanged completely every $15 \mathrm{~min}$. Redrawn buffer was immediately centrifuged at $4^{\circ} \mathrm{C}$ at $9000 \mathrm{~g}$ for $5 \mathrm{~min}$ and the supernatants were subsequently frozen and stored at $-80^{\circ} \mathrm{C}$ until assay of renin. Experiments were run for seven 15 -min cycles. Potassium concentration was changed isoosmotically during the 4 th and 5 th cylces. Renin releasing rates were related to the value obtained in the 3 rd cycle (i.e. $100 \%$ of control). Experiments with material obtained from 7 mice were performed.

\section{Rat tissue}

Renin release from glomeruli. Male Sprague-Dawley rats $(250-350 \mathrm{~g})$ with previous free access to food and water were anesthetized with sodium amobarbital ( $12.5 \mathrm{mg} / 100 \mathrm{~g}$ body weight i.p.). Batches of 300 glomeruli with attached juxtaglomerular cells were prepared by the magnetic iron technique and were mounted separately in five polyethylene catheters (Blendstrup et al. 1975). The glomeruli were held by a magnetic field during superfusion at a rate of $10 \mu \mathrm{l} / \mathrm{min}$ from one of two pumps (Braun, Melsungen, FRG) each mounted with five infusion syringes. At zero time the superfusion was shifted to the second pump with five syringes containing experimental solution or control Ringer solution. All experiments were performed at a temperature of $30^{\circ} \mathrm{C}$. The glomeruli were prepared in a bicarbonate Ringer solution of the following composition (mmol/l): $\mathrm{NaCl} 101.0, \mathrm{NaHCO}_{3} 17.5, \mathrm{KCl} 7.0$, $\mathrm{CaCl}_{2} 2.0, \mathrm{MgSO}_{4} 1.2, \mathrm{NaH}_{2} \mathrm{PO}_{4} 1.2$, glucose 11.0 and sucrose 30.0 , giving a calculated osmolality of $301 \mathrm{mosmol} / \mathrm{kg}$. The solution was adjusted to $\mathrm{pH} 7.3$ by bubbling with $4 \% \mathrm{CO}_{2}$ and $96 \% \mathrm{O}_{2}$ at $37^{\circ} \mathrm{C}$. The renin concentration was measured by radioimmunoassay of the angiotensin I generated (Poulsen and Jorgensen 1974). A $25 \mu \mathrm{I}$ sample of superfusate was added to $25 \mu 1$ mixture of angiotensin I antibody and substrate-enriched rat plasma. The samples were incubated for $3 \mathrm{~h}$ at $37^{\circ} \mathrm{C}$. After the experiments the remaining renin in the batches was extracted by freezing and thawing three times. The absolute value of renin release in the last period preceeding the zero time was used for normalizing the renin release rate in the individual experiments. The term 'total renin content' refers to the amount of renin remaining in the glomeruli after the experiment plus the amount of renin released during the experiment. The absolute renin values are expressed in terms of standard Goldblatt Units (GU). The significances were calculated by Student's $t$-test with Bonferronis reduction for multiple comparisons. $P<0.05$ was considered significant.

\section{Results}

As a first approach to demonstrate the existence of voltagegated calcium channels we looked for potential-dependent calcium currents in JG cells. Typical current records under voltage clamp (Fig. 1) and the resulting current-voltage relationship (Fig. 1) in a JG cell under standard conditions display inward and outward rectifying potassium currents (Kurtz and Penner 1989). To render voltage-operated calcium currents more prominent these rectifying currents were blocked by substituting intracellular potassium by cesium and by addition of tetraethylammonium $(10 \mathrm{mmol} / \mathrm{l})$ to external and internal solutions. Moreover, intracellular calcium was buffered to $150 \mathrm{nmol} / \mathrm{l}$ (with a mixture of internal CaEGTA/K $\mathrm{K}_{2}$ EGTA at a ratio of $5 / 5 \mathrm{mmol} / \mathrm{l}$ ) to avoid interference with calcium-activated chloride currents (Kurtz and Penner 1989), and extracellular calcium was raised to $10 \mathrm{mmol} / \mathrm{l}$ to increase the inward driving force for calcium. However, the resulting current records (Fig. 1) and the resulting current-voltage relationship (Fig. 1) did not provide evidence for inward currents of the kind typical for voltage-gated calcium currents $(n=9)$.

As an alternative approach to searching for potentialoperated calcium channels we examined the influence of the membrane potential on the intracellular concentration of calcium. Typical recordings of intracellular calcium in JG cells during repetitive membrane de- and hyperpolarization are shown in Fig. 2. Apparently, membrane depolarization had no effect on [Ca $]_{\mathrm{i}}(n=100)$, while ionomycin $(n=6)$ (Fig. 2A) and angiotensin II ( $n=46)$ (Fig. 2B) elicited large rises of $[\mathrm{Ca}]_{\mathrm{i}}$ in the cells. Conversely, $[\mathrm{Ca}]_{\mathrm{i}}$ increased during hyperpolarizing pulses for $4 \mathrm{~min}$ after the application of angiotensin II, indicating an increase of the calcium permeability of the cell membrane during this period (Penner et al. 1988). These findings demonstrate that the technique 


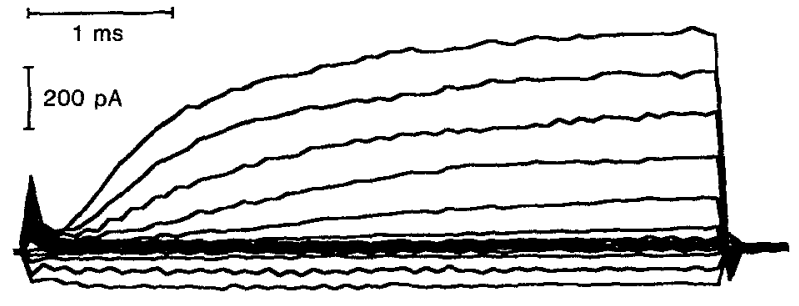

Fig. 1. Steady-state whole cell currents evoked by stepping the membrane potential from $-70 \mathrm{mV}$ to various levels (from -115 to +50 $\mathrm{mV}$ ). Left upper: standard external and internal solutions; left lower: external solution supplemented with $10 \mathrm{mmol} / \mathrm{l}$ tetraethylammonium (TEA) and $10 \mathrm{mmol} / 1 \mathrm{CaCl}_{2}$; internal solution supplemented with 10 mmol/1 TEA, CaEGTA $/ \mathrm{K}_{2}$ EGTA $5 / 5 \mathrm{mmol} / \mathrm{l}$, potassium glutamate substituted by $\mathrm{CsCl}_{2}$. Right: steady-state current-voltage relationships derived from left panels ( $\boldsymbol{Q}$, upper; $\bigcirc$, lower panel)

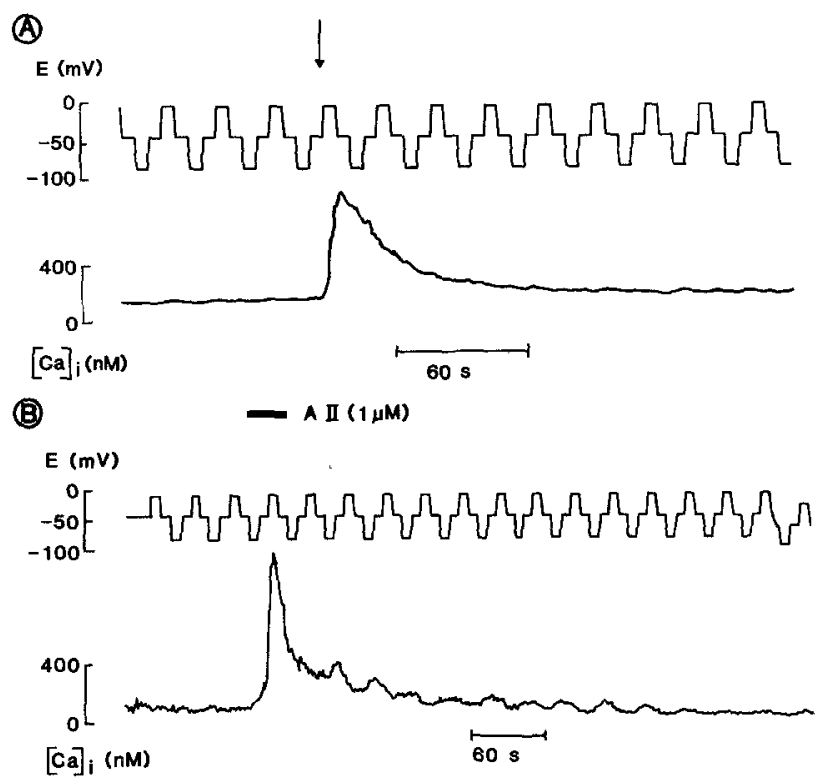

Fig. 2. Intracellular calcium concentration in mouse juxtaglomerular (JG) cells during hyper- and depolarizing voltage pulses and application of ionomycin (5 mg/l) (arrow, upper panel) and angiotensin II $(1 \mu \mathrm{mol} / 1)$ (bar, lower panel)

applied allows the detection of changes of intracellular calcium brought about by unspecific (ionomycin) or receptoractivated, second-messenger-operated increases of the calcium permeability of JG cell plasma membranes.

Under voltage clamp, increases of the extracellular concentration of potassium evoked currents with a reversal potential close to the potassium equilibrium potential $(n=15)$ (Fig. 3A), indicating that the membrane potential is close to the potassium equilibrium potential. Increases of potassium had no effect on $[\mathrm{Ca}]_{i}$ neither in voltage-clamped

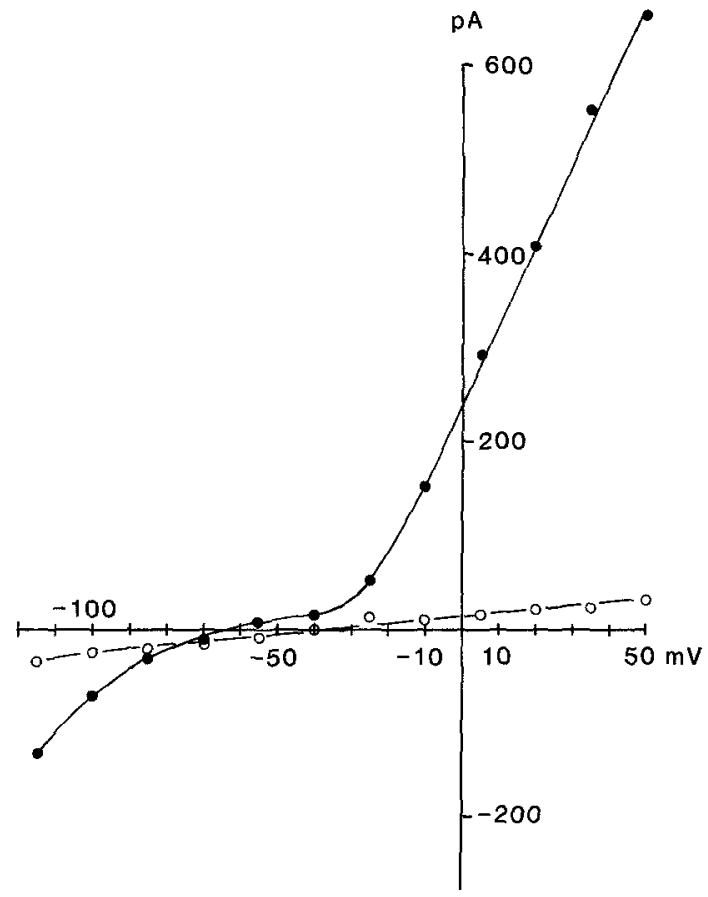

(A)
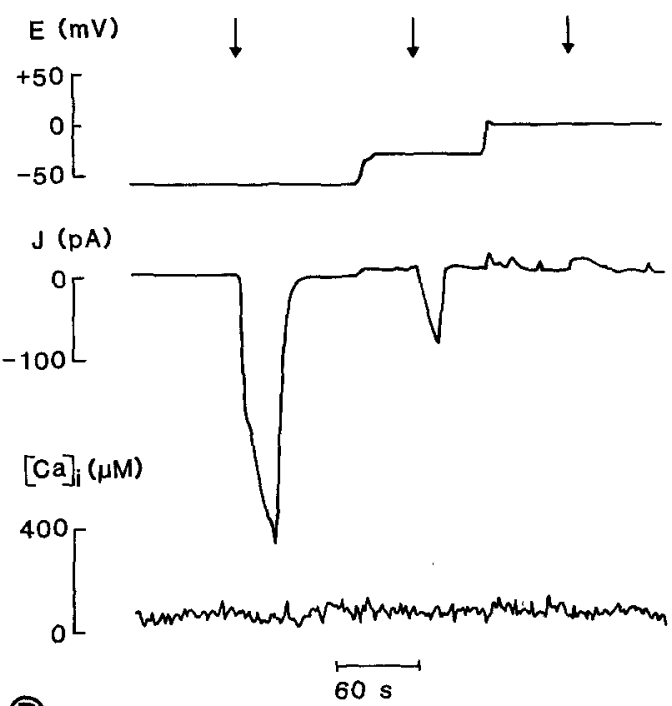

(B)

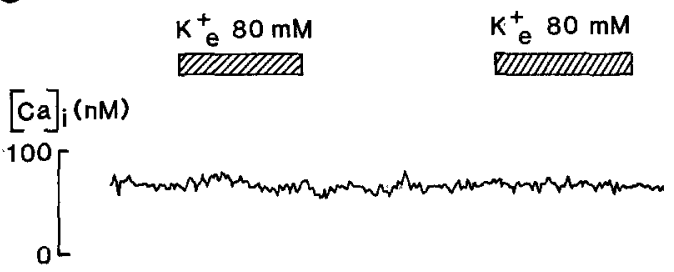

Fig. 3. A. Recordings of membrane potential, whole-cell currents and intracellular calcium concentration in a JG cell during repetitive application of high extracellular potassium $(80 \mathrm{mmol} / \mathrm{h})$ as indicated by arrows. B. Recording of intracellular calcium in an intact JG cell loaded with Fura 2 acetoxymethyl ester during application of high extracellular potassium. 
$(n=15)$ (Fig. 3A) nor in current-clamped $(n=10)$ (not shown) JG cells. To rule out the possibility that the patchclamp conditions could have caused the functional disappearance of potential-operated calcium channels, we also examined the effect of high extracellular potassium on intact JG cells loaded with Furaester $(n=16)$ (Fig. 3B). Again, potassium depolarization did not alter the intracellular concentration of calcium.

Since we did not obtain direct evidence for the existence of voltage-gated calcium channels we looked for a functional role of voltage-operated calcium channels in renin secretion from intact JG cells. To this end we measured renin secretion from the tissue preparation used for the experiments mentioned before. The material retained by the $50-\mu \mathrm{m}$ sieve was loaded on Sephadex G-50 columns and superfused with extracellular buffer. Basal renin release from the preparation was stable 30-40 min after onset of the experiment (Fig. 4A). Addition of angiotensin II $(100 \mathrm{nmol} / \mathrm{l})$ led to a reversible inhibition of renin secretion to about $50 \%$ of the control value (Fig 4B). Change of the concentration of extracellular potassium $(1.4-90 \mathrm{mmol} / \mathrm{l})$ with simultaneous changes of sodium, in order to keep the osmolality constant, did not affect renin secretion significantly (Fig. 5), although there was a tendency towards higher renin secretion rates at high extracellular potassium. At low concentrations of extracellular potassium $(0.7 \mathrm{mmol} / \mathrm{l})$ renin secretion tended to decrease. Since the inhibitory effect of high extracellular potassium on renin secretion was predominantly reported for kidney slices, we also utilized this experimental model. And, in fact, raising the extracellular potassium from 5 $\mathrm{mmol} / \mathrm{l}$ to $56 \mathrm{mmol} / \mathrm{l}$ caused a significant $(p<0.05)$ decrease of renin secretion from mouse kidney slices (Table 1) with a delay of $15 \mathrm{~min}$. However, with the same delay time an increase of extracellular potassium to $112 \mathrm{mmol} / 1$ led to a significant increase of spontaneous renin release from kidney slices.

To test whether the lack of inhibition by high extracellular potassium on renin secretion from the preparation enriched in mouse JG cells was specific for mouse renal tissue (Fig. 5), we also examined the effect of depolarizing concentrations of potassium on renin secretion from rat superfused glomeruli. The spontaneous renin release from those superfused glomeruli with attached juxtaglomerular cells declined slowly with time, as seen in the semilog plot

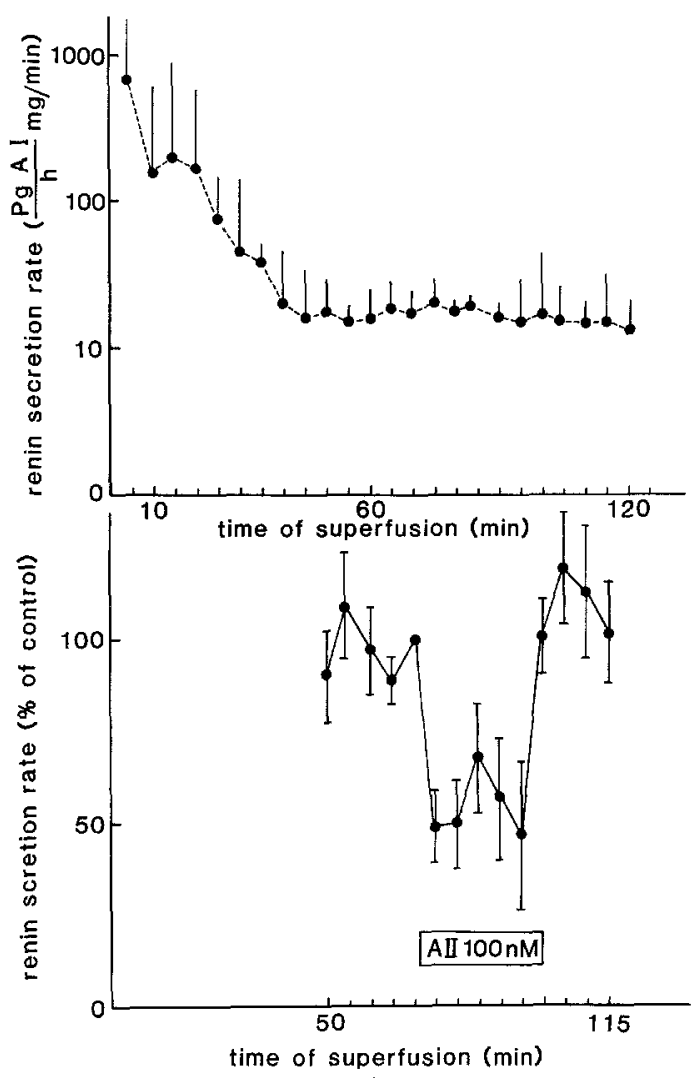

Fig. 4. Upper panel: typical time course of spontaneous renin release from the tissue preparation used for patch-clamp and calcium measurement experiments. Data are mean \pm SEM of triplicate columns from one preparation. Lower panel: spontaneous renin release before, during and after addition of angiotensin II $(100 \mathrm{nM})$ to the perfusate. Values are related to last sample before addition of angiotensin II $(100 \%$ of control). Data are mean \pm SEM of eight independent experiments

of Fig. 6. Addition of depolarizing amounts of $\mathrm{KCl}(56$ $\mathrm{mmol} / 1$ ) under isoosmotic conditions even caused a stimulation of renin release. The average basal renin release rate $(n=43)$ at zero time was $6.81 \pm 0.98(\mathrm{SE}) \mu \mathrm{GU} / 300$ glomeruli over $12 \mathrm{~min}$. The average renin content of the batches of glomeruli was $1.28 \pm 0.20$ (SE) $\mathrm{mGU} / 300$ glomeruli $(n=43)$.

Table 1. Effect of extracellular potassium concentration on renin secretion from mouse kidney slices $^{\text {a }}$

\begin{tabular}{rlrlrrrrr}
\hline$[\mathrm{K}]_{\mathrm{o}}(\mathrm{mM})$ & \multicolumn{6}{l}{ Renin secretion (\%) after the following times (min) } \\
\cline { 2 - 8 } & $15-30$ & $30-45$ & $45-60$ & $60-75$ & $75-90$ & $90-105$ & $105-120$ \\
\hline $5(n=13)$ & $206 \pm 14$ & $149 \pm 10$ & 100 & $114 \pm 20$ & $82 \pm 13$ & $82 \pm 13$ & $81 \pm 20$ \\
$28(n=4)$ & $208 \pm 29$ & $168 \pm 14$ & 100 & $115 \pm 21$ & $102 \pm 14$ & $93 \pm 16$ & $93 \pm 19$ \\
$56(n=13)$ & $190 \pm 21$ & $121 \pm 9$ & 100 & $86 \pm 9$ & $62 \pm 13^{*}$ & $82 \pm 19$ & $98 \pm 21$ \\
$112(n=5)$ & $260 \pm 41$ & $207 \pm 47$ & 100 & $136 \pm 10$ & $135 \pm 5^{*}$ & $95 \pm 13$ & $89 \pm 12$ \\
\hline
\end{tabular}

${ }^{a}$ Renin secretion rates are given as percentages (means $\pm \mathrm{SE} ; n$ ) of control period, for which the 45-60 min interval was chosen. Extracellular potassium concentration was isoosmotically changed from $5 \mathrm{mM}$ to the indicated value during the 60 th-75th and 70th-95th-min intervals. Absolute values for renin secretion during the control periods were $93 \pm 3 \mathrm{ng}$ (mean $\pm \mathrm{SE}$; $(n=35)$ angiotensin $\mathrm{I} / \mathrm{h}$ over $15 \mathrm{~min}$ and for $100 \mathrm{mg}$ wet weight

$* P<0.05$ vs control series, which received $5 \mathrm{mM} \mathrm{K}$ throughout 


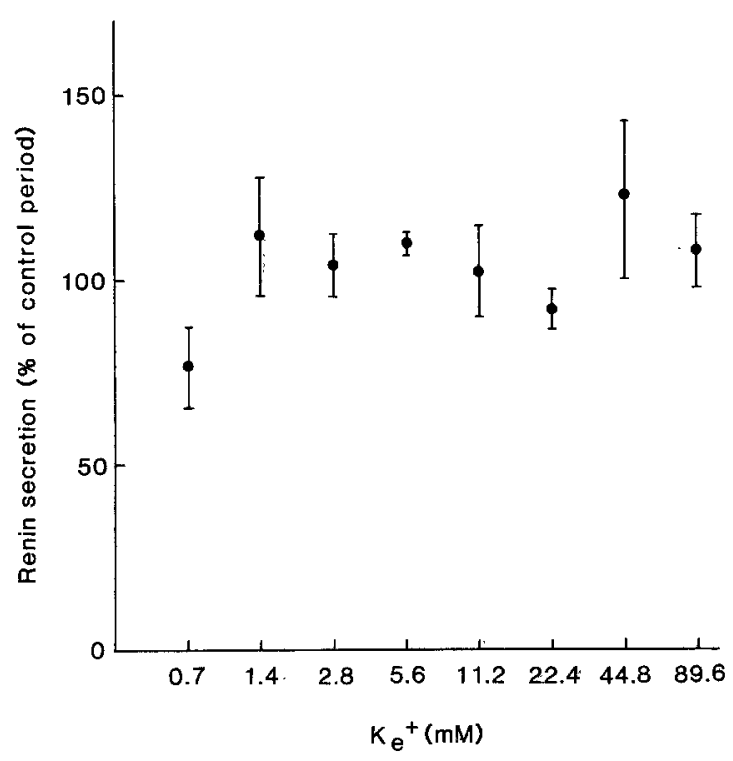

Fig. 5. Spontaneous renin release from the tissue preparation after changing extracellular potassium to various concentrations between the 75 th and 95 th min of superfusion. Renin release during this period is related to that of the respective control period (50th-70th min). Data are means \pm SEM of three independent experiments each

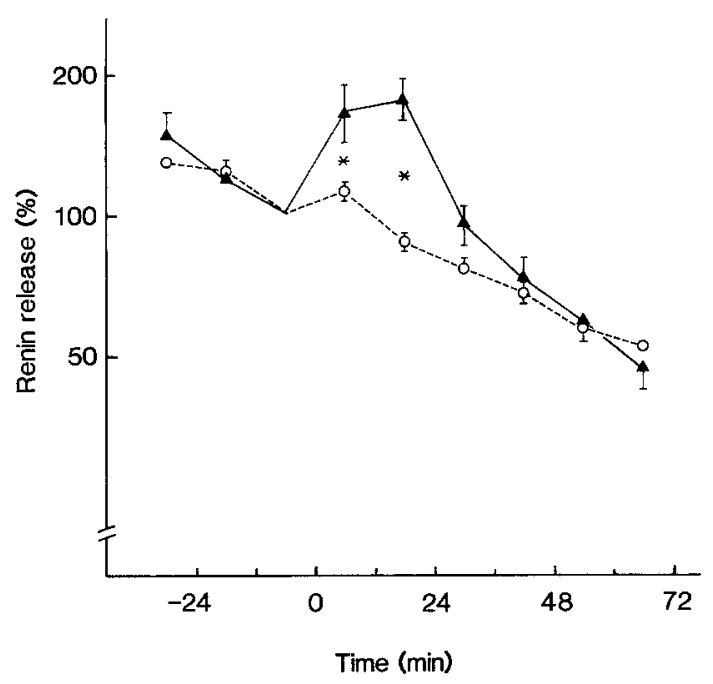

Fig. 6. Effects of depolarizing concentrations of $\mathrm{KCl}$ on renin release from superfused rat glomeruli. $\mathrm{K}$ was changed at time zero. Time control experiments $(O, n=18)$ show a slowly decreasing release rate. Depolarization induced by addition of $56 \mathrm{mM} \mathrm{KCl}$ with simultaneous reduction of $\mathrm{NaCl}$ by $56 \mathrm{mM}$ stimulated renin release significantly $(\Lambda, n=15)$. Bars indicate \pm SE. Note the semilogarithmic scale

\section{Discussion}

Renin-containing cells in the afferent arterioles have been found to extend up to $100 \mu \mathrm{m}$ from the glomerular vascular pole (Taugner et al. 1982). We have therefore focussed our experiments on this anatomical region. For this study we have examined 150 cells taken from a total of 54 mice and we have obtained no evidence for heterogeneities among the cells, an observation that is in accordance with recent studies (Bührle et al. 1985; Kurtz and Penner 1989). Our primary aim was to examine the role of voltage-operated calcium channels in the regulation of intracellular calcium in renal JG cells. However, we obtained no evidence for the existence of voltage-activated calcium currents in mouse JG cells.

The patch-clamp measurements did not reveal inwards currents that are typical for voltage-operated $\mathrm{Ca}^{2+}$ channels (Bean et al. 1986; Yatani et al. 1987). Membrane depolarization should cause activation of calcium currents and in consequence rises of $[\mathrm{Ca}]_{\mathrm{i}}$ (Becker et al. 1989). However, this maneuver was ineffective in mouse JG cells. To narrowdown possible artefacts due to very fast run-down kinetics of voltage-operated $\mathrm{Ca}^{2+}$ channels under patch-clamp conditions (Tanita 1988) membrane depolarization was also induced by raising extracellular potassium in clamped and in intact $\mathrm{JG}$ cells. Also under these conditions $[\mathrm{Ca}]_{\mathrm{i}}$ did not change upon membrane depolarization (Fig. 3).

The effect of depolarizing concentrations of potassium on renin secretion were dependent on the experimental model used. While high $\left[\mathrm{K}^{+}\right]_{0}$ tended to increase renin secretion from the preparation used for the patch-clamp experiments (Fig. 5), it had a biphasic effect on renin secretion from mouse kidney slices (Table 1). At a concentration of $56 \mathrm{mmol} / 1$, K caused a delayed reduction of spontaneous renin release. At a concentration of $112 \mathrm{mmol} / \mathrm{l}$ it led to an increase of renin release. When rat glomeruli with attached JG cells were used, depolarizing concentrations of $\mathbf{K}^{+}$(56 $\mathrm{mmol} / \mathrm{l}$ ) did not inhibit but in fact stimulated renin secretion from rat JG cells, when the change of potassium was made isoosmotically (Fig. 6). Although surprising at first view, the observed stimulation of renin secretion by high $\left[\mathrm{K}^{+}\right]_{0}$ is in accordance with the findings of Beierwaltes et al. (1981) and Frederiksen et al. (1975), obtained with similar preparations of rat JG cells. It should be noted in this context that high extracellular potassium also stimulates renin secretion in the isolated perfused rat kidney (Fray 1980) and hog kidney slices (Park and Malvin 1978) if extracellular calcium is low, and inhibits it at normal or. high calcium concentrations (Churchill 1980, 1987; Matsumura 1984; Park et al. 1981; Fray et al. 1987, Fray 1980; Park and Malvin 1978). Our finding that extracellular potassium at $56 \mathrm{mmol} /$ 1 inhibits renin secretion from mouse kidney slices fits with those observations. The inhibitory effect of potassium occurred with a delay of about $15 \mathrm{~min}$, a time interval that might have been overlooked in experiments performed by others, who used incubation times of $30 \mathrm{~min}$ or even longer and where renin secretion rates were calculated from the change of accumulative renin activity in the incubation buffer. The significant delay could suggest an-indirect effect of potassium. Supportive to this idea is our observation that the concentration (and in consequence the potential) dependence of the potassium effect on renin secretion from renal slices does not fit well with the activation and inactivation of voltage-gated calcium channels. We have recently developed a hypothesis suggesting that extracellular potassium could affect renin secretion in a calcium-dependent fashion via a change of the JG cell volume, without activating voltage-operated calcium channels (Kurtz 1990). Moreover, the possibility cannot be excluded that the inhibitory effect of high potassium on renin secretion from kidney slices is mediated by the release of factors that in turn act 
on JG cells via calcium channels. Such factors could, for instance, include endothelial-derived relaxing factor (Vidal et al. 1988) and endothelin (Raguki et al. 1988), which have been found to inhibit renin secretion from JG cells. A recent and very interesting finding in this context is that endothelin causes contraction of rat aorta and portal vein by enhancing calcium entry (Borges et al. 1989). Both calcium entry and contraction by endothelin were blunted by low concentrations of dihydropyridines. Clear evidence, however, was provided in that study that endothelin did not activate voltage-operated $\mathrm{Ca}^{2+}$ channels. This finding suggests the existence of calcium channels that are susceptible to organic channel blockers in a fashion typical for voltage-operated channels but are different from these.

It could be possible, therefore, that the facilitatory effect of organic calcium-channel blockers on renin secretion is also not due to the inactivation of voltage-operated $\mathrm{Ca}^{2+}$ channels. A somewhat special effect to these drugs is that they already stimulate basal renin secretion (Kurtz et al 1986; May and Peart 1984; Antonipillai and Horton 1985; Henrich and Campbell 1986), while they do not affect calcium entry into unstimulated or resting smooth muscle cells (cf. Loutzenhiser and Epstein 1985). Circumstantial evidence, moreover, suggests that the calcium channels in the juxtaglomerular region could have some unusual characteristics. For instance, there is broad evidence that the constrictory effect of angiotensin II on afferent and efferent vessels is highly dependent on calcium entry (cf. Loutzenhiser and Epstein 1985). Recently it was shown that the constrictory effect of angiotensin II is blunted by dihydropyridines in the proximal afferent vessel but is not at all affected in the efferent vessel (Carmines and Navar 1989) suggesting that the susceptibility of the calcium entry mechanisms to organic calcium channel blockers changes strikingly from the proximal afferent to the efferent vessel. Churchill (1988) has pointed out that the inhibitory effect of angiotensin II on renin secretion, which is associated with depolarization of JG cells (Bührle et al. 1985), is dependent on calcium entry but independent of voltage-operated $\mathrm{Ca}^{2+}$ channels. In addition the current-voltage relationship in rat JG cells does not display inward currents such as would be characteristic for the activation of voltage-operated $\mathrm{Ca}^{2+}$ channels (Bührle et al. 1985). On the other hand there is evidence for calcium entry in JG cells caused by angiotensin II that is blocked by verapamil (Kurtz et al. 1985; Kurtz and Penner 1989; Fig. 2). From the observation that membrane hyperpolarization instead of depolarization enhances this calcium influx (Fig. 2B) we infer that this effect of angiotensin II is mediated by receptor-operated calcium channels rather than by recruitment of covert voltage-operated channels.

Evidence that receptor-operated $\mathrm{Ca}^{2+}$ channels are in fact susceptible to organic calcium channel blockers has already been provided (Borges et al. 1989).

We will not doubt the existence of voltage-operated $\mathrm{Ca}^{2+}$ channels in renal vasular smooth muscle cells. During our experiments we have observed that fragments of larger arteries, such as interlobary or arcuate arteries, respond with prompt contraction upon exposure to high extracellular potassium. The afferent vessels, and in particular the juxtaglomerular region, however, were insensitive to high $\mathrm{K}$ but contracted promptly in response to angiotensin II. These preliminary observations could indicate that renal vascular smooth muscle cells more distant from the juxtaglomerular region contain voltage-operated $\mathrm{Ca}^{2+}$ channels. The tight envelope with connective tissue, however, prevented successful patch-clamp recordings from smooth muscle cells in larger arteries, although we made a number of attempts.

Summing up, our findings suggest that voltage-operated $\mathrm{Ca}^{2+}$ channels play no direct role in renal JG cells. The effect of extracellular potassium on renin secretion from renal slices awaits a definitive explanation, but it might be due to an indirect inhibitory effect of potassium.

Acknowledgements. The skilful technical assistance given by Conni Temdrup and Werner Gehret is gratefully acknowledged. This study was financially supported by the Schweizerischer Nationalfonds (grant 3.800-0.86), by the Deutsche Forschungsgemeinschaft (grant Pe-243/ 1) and the Danish Medical Research Council. A.K. acknowledges fellowships of the Max-Planck-Foundation and the Kanton of Zürich.

\section{References}

Abe X, Yukimura T, Iwao H, Mori N, Okahara T, Yamamoto K (1983) Effects of EDTA and verapamil on renin release in dogs. Jpn $J$ Pharmacol 33: 627-633

Antonipillai I, Horton R (1985) Role of extra- and intracellular calcium and calmodulin in renin release from rat kidney. Endocrinology 117: 601-606

Bean BP, Sturek M, Puga A, Hermsmeyer K (1986) Calcium channels in muscle cells isolated from rat mesenteric arteries. Cir Res 59: 229-235

Becker PL, Singer JJ, Walsh JV, Fay FS (1989) Regulation of calcium concentration in voltage clamped smooth muscle cells. Science 244 : 211-214

Beierwaltes WH, Schryner S, Olson PS, Romero JC (1981) Control of renin release in isolated rat glomeruli. Hypertension 3 [Suppl II]: II30-II34

Blendstrup K, Leyssac PP, Poulsen K, Skinner SL (1975) Characteristics of renin release from isolated superfused glomeruli in vitro. J Physiol (Lond) 246: 653-672

Borges R, Carter DV, v. Grafenstein H, Halliday J, Knight DE (1989) Ionic requirements of endothelin response in aorta and portal vein. Circ Res 65: 265-271

Bührle CP, Nobiling R, Taugner R (1985) Intracellular recordings from renin-positive cells of the afferent glomerular arteriole. Am J Physiol 249: F272-F281

Carmines PK, Navar LG (1989) Disparate effects of Ca channel blockade on afferent and efferent arteriolar responses to ANG II. Am J Physiol 256: F1015-F1020

Churchill PC (1980) Effect of D-600 on inhibition of in vitro renin release in the rat by high extracellular potassium and angiotensin II. J Physiol (Lond) 304: 449-458

Churchill PC (1987) Calcium channel antagonists and renin secretion. Am. J Nephrol 7 [Suppl 1]: 32-38

Churchill PC (1988) Cellular mechanisms of renin release. Clin Exp Hypertens [A] 10: 1189-1202

Fishman MC (1976) Membrane potential of juxtaglomerular cells. Nature 260: 542-544

Fray JCS (1978) Stretch receptor control of renin release in perfused rat kidney: effect of high perfusate potassium. J Physiol (Lond) 282: $207-217$

Fray JCS (1980) Mechanism by which renin secretion from perfused rat kidneys is stimulated by isoprenaline and inhibited by high perfusion pressure. J Physiol (Lond) 308: 1-13 
Fray JCS, Park CS, Valentine AND (1987) Calcium and the control of renin secretion. Endocrine Rev 8: 53-93

Frederiksen O, Leyssac PP, Skinner SL (1975) Sensitive osmometer function of juxtagiomerular cells in vitro. J Physiol (Lond) 252: 669-679

Glynkiewicz G, Poenie M, Tsien RY (1985) A new generation of $\mathrm{Ca}^{2+}$ indicators with greatly improved fluorescence properties. J Biol Chem 260: 3440-3450

Henrich WL, Campbell WB (1986) Importance of calcium in renal renin release. Am J Physiol 251: E98-E103

Kurtz A (1990) Do calcium activated chloride channels control renin secretion? News Physiol Sci (in press)

Kurtz A, Penner R (1989) Angiotensin II induces oscillations of intracellular calcium and blocks anomalous inward rectifying potassium current in mouse renal juxtaglomerular cells. Proc Natl Acad Sci USA 86: 3423-3427

Kurtz A, Pfeilschifter J, Hutter A, Bührle C, Nobiling R, Taugner R, Hackenthal E, Bauer C (1986) Role of protein kinase C in inhibition of renin release caused by vasoconstrictors. Am J Physiol 250: C563-C571

Loutzenhiser R, Epstein M (1985) Effects of calcium antagonists on renal hemodynamics. Am J Physiol 249: F619-F629

Matsumura Y, Miyakawaki N, Morimoto S (1984) Effects of W-7 and W-5 on renin release from rat kidney slices. Jpn J Pharmacol 36: 268-271

Matsumura Y, Sasaki Y, Shinyama H, Morimoto S (1985) The calcium channel agonist, Bay $\mathrm{K} 8644$, inhibits renin release from rat kidney slices. Eur J Pharmacol 117: 369-372

May CN, Peart WS (1984) The role of calcium in the control of renin release. J Hypertens 2 [Suppl 3]: 243-245
Neher E (1988) The influence of intracellular calcium concentration on degranulation of dialysed mast cells from rat peritoneum. J Physiol (Lond) 295-193-214

Park CS, Malvin RL (1978) Calcium in the control of renin release. Am J Physiol 235: F22-F25

Park CS, Malvin RL (1978) Calcium in the control of renin secretion: $\mathrm{Ca}^{2+}$ influx as an inhibitory signal. Am J Physiol 240: F70-F74

Penner R, Neher E (1988) The role of calcium in stimulus-secretion coupling in excitable and non-excitable cells J Exp Biol 139: 329 345

Penner R, Matthews G, Neher E (1988) Second messenger control of calcium influx in rat peritoneal mast cells. Nature 334: 499-504

Poulsen K, Jorgensen J (1974) An easy radio-immunological microassay of renin activity, concentration and substrate in human and animal plasma and tissues based on angiotensin-I trapping by antibody. J Clin Endocrinol Metab 39: 816-825

Raguki H, Nakamaru M, Saito H, Higaki J, Ogihara T (1988) Endothelin inhibits renin release from isolated rat glomeruli. Biochem Biophys Res Commun 155: 1244-1247

Tanita T (1988) Ionic channels in smooth muscle studied with patchclamp methods. Jpn J Physiol 38: 1-18

Taugner R, Marin-Grez M, Keilbach R, Hackenthal E, Nobiling R (1982) Immunoreactive renin and angiotensin II in the afferent glomerular arterioles of rats with hypertension due to unilateral renal artery constriction. Histochemistry 76: 61-69

Vidal MJ, Romero JC, Vanhoutte PM (1988) Endothelium-derived relaxing factor inhibits renin release. Eur J Pharmacol 149: 401402

Yatani A, Desiel CL, Allen J, Brown AM (1987) Whole-cell and singlechannel calcium currents of isolated smooth muscle cells from saphenous vein. Circ Res 60: 523--533 